\title{
MODEL MANAJEMEN PERPUSTAKAAN RUMAH PINTAR PADA RUMAH PINTAR ORGANISASI WANITA ISLAM, DUREN SAWIT, KLENDER, JAKARTA TIMUR
}

\author{
Durotul Yatimah \\ Universitas Negeri Jakarta \\ e-mail : yatimahdurotul2018@gmail.com
}

\begin{abstract}
Education is something really important for everyone, good formal education, in-formal and non-formal . The implementation of education non-formal aims to the delivery of education to the community outside an education channel formal.salah one an education channel non-formal is sentra read or library. Management of libraries house smart it is important that this library capable of actually deliver education for the, good in urban children in school, teenagers, or mothers an elderly. The problem, is it really the clever library has been portrayed as a community empowerment, function still requires penelitian.penelitian devoted to know how clever it is the management of libraries so it is really able to provide education for the.Urgency this study is to find mberikan library services and development of community competence can be served through formal education. Managerial ability perpustkaan built through training and guidance for the study, so titu benar-benar derived from the library, personnel and facilities from residents learned, the management of learning and learning and the user community residents. The library is one of the smart alternative to do langkah-langkah important for community empowerment .In connection with it, writer interested to study of management library of smart organization muslim women.

The purpose of this research to know a model management of libraries, obstacles faced residents learn, as well as efforts to build the other financial markets grow managerial competence of libraries in the islam.konsep used are ( 1 ) management ( 2 ) library in pls ( 3 ) smart house. Research methodology is the method descriptive. The results of the study show that the model library management organization of muslim women, begins with ( 1 planning a library to good and orderly, good administratively, and in terms of human resources and facilities of his supporters sesui with the results of the analysis the needs of citizens of learning and the community. Training people learn to have competence to manage the library with good. ( 2 ) organizing resources, orderly including the procurement of books and reference is in accordance with the needs of residents of learning and the community ( 3 ) a move for the providing of, book the arrangement, the care and security book sought by people learn and relevant to the purpose of the establishment of the library ( 4 ), coaching coaching and provide assistance to the people learn in accordance with the needs of her studies and coaching at users who from the surrounding. ( 5 ) monitoring and supervision on the use of library facility to continue to strpembinaan on ategis memabngun and conducive in reading learning ( 6 ) aspects of its development, so that the library able to give pleasing and build the motivation to study, either by technical service, non-technical in nature and which are in umum.luara management research was the teaching.

A conclusion, the library of the organization of muslim women are staffed with management fungsi-fungsi necessary to ensure that effective, yet from either the citizen looking for a good place, by the citizens of learning dedicated to local residents and to support learning and masyarakat.semua the function of the management of the library was a controlled by the management or, and police were deployed in the whole ideas to the community, energy and force and their potential support comfort looking for a good place, as well as guarantee the the interaction that transactional dialogic with users the library.

Finally the library is expected to continue to grow, appeal and strengthening the interest of users to keep reading that, that can improve, knowledge mental powers, patten life and independency the users which in turn gradually empower life of the study and the community.
\end{abstract}

Keywords: Library Management ,Smart House, Residents Learned, Community Empowerment 


\begin{abstract}
Abstrak
Pendidikan merupakan hal sangat penting bagi setiap orang, baik pendidikan formal, in-formal maupun non-formal. Penyelenggaraan pendidikan non formal bertujuan untuk memberikan pelayanan pendidikan kepada masyarakat di luar jalur pendidikan formal.Salah satu jalur pendidikan non formal adalah sentra baca atau perpustakaan. Pengelolaan Perpustakaan Rumah Pintar merupakan hal penting agar perpustakaan ini mampu benar-benar memberikan pendidikan bagi masyarakat, baik ditingkat anak-anak usia sekolah, remaja, ataupun ibu-ibu yang lanjut usia. Masalahnya,apakah benar perpustakaan Rumah Pintar ini telah memerankan fungsi sebagai ajang pemberdayaan masyarakat, masih memerlukan penelitian.Penelitian ditujukan untuk mengetahui bagaimanakah pengelolaan Perpustakaan Rumah Pintar ini sehingga benarbenar mampu memberikan pendidikan bagi masyarakat. Urgensi penelitian ini adalah untuk mengetahui mberikan layanan perpustakaan dan pengembangan kompetensi masyarakat yang tidak dapat terlayani melalui pendidikan formal. Kemampuan managerial perpustkaan dibangun melalui pelatihan dan pembinaan kepada warga belajar, sehingga perpustakaan titu benar-benar berasal dari pemikiran,tenaga dan fasilitas dari warga belajar, pengelolanya warga belajar dan penggunanya warga belajar dan masyarakat. Perpustakaan rumah pintar merupakan salah satu alternatif untuk melakukan langkah-langkah penting bagi pemberdayaan masyarakat. Sehubungan dengan itu,penulis tertarik untuk meneliti tentang manajemen perpustakaan rumah pintar organisasi wanita Islam.

Tujuan penelitian ini untuk mengetahui model pengelolaan perpustakaan, kendala yang dihadapi warga belajar,serta upaya untuk membangun tumbuhnya kompetensi managerial perpustakaan di organisasi Wanita Islam.Konsep yang digunakan meliputi (1) manajemen (2) perpustakaan dalam PLS (3)rumah pintar. Metode penelitian adalah metode deskriptif. Hasil penelitian menunjukan bahwa model manajemen perpustakaan organisasi wanita Islam, dimulai dengan (1)perencanaan perpustakaan yang baik dan teratur, baik secara administratif,maupun dari sisi sumber daya manusia dan fasilitas pendukungnya sesui dengan hasil analisis kebutuhan warga belajar dan masyarakat. Melatih warga belajar agar memiliki kompetensi untuk mengelola perpustakaan dengan baik.(2)pengorganisasian sumber daya yang tertib,termasuk pengadaan buku dan referensi yang sesuai dengan kebutuhan warga belajar dan masyarakat (3) pergerakan pada kegiatan pengadaan buku, penataan, perawatan dan penjagaan keamanan buku yang diminati warga belajar dan relevan dengan tujuan pendirian perpustakaan (4)Pembinaan, pembimbingan dan pendampingan pada warga belajar sesuai dengan kebutuhan belajarnya dan pembimbingan pada pengguna yang berasal dari masyarakat sekitarnya. (5)monitoring dan pengawasan terhadap penggunaan sarana dan fasilitas perpustakaan agar terus strpembinaan pada ategis dan kondusif dalam memabngun minat baca warga belajar (6) aspek pengembangannya, agar perpustakaan mampu memberikan layanan menyenangkan dan membangun motivasi belajar, baik dengan layanan teknis, nonteknis maupun yang sifatnya pengelolaan secara umum. Luara Penelitian adalah buku ajar,

Kesimpulan, perpustakaan organisasi wanita Islam dikelola dengan fungsi-fungsi managemen yang efektif, dari warga belajar,oleh warga belajar untuk warga belajar dan masyarakat.Semua fungsi manajemen perpustakaan itu dikendalikan oleh pengelola, dengan mengerahkan seluruh pemikiran,energi dan kekuatan serta potensi yang mendukung kenyamanan belajar, serta menjamin interaksi yang transactional dialogic dengan pengguna perpustakaan. Akhirnya perpustakaan diharapkan terus berkembang, memiliki daya tarik dan memperkuat minat pengguna untuk terus membacanya,sehingga mampu meningkatkan pengetahuan, kekuatan mental,pola hidup dan keberdayaan penggunanya yang pada akhirnya secara bertahap mampu memberdayakan kehidupan warga belajar dan masyarakat.
\end{abstract}

Kata kunci : manajemen perpustakaan, rumah pintar, warga belajar,pemberdayaan masyarakat

\section{PENDAHULUAN}

$\begin{array}{rr} & \text { Pendidikan merupakan upaya } \\ \text { untuk membentuk watak serta }\end{array}$

kepribadian yang akan memperkaya

pengetahuan manusia dan masyarakat

serta kemampuan professional.

Pendidikan ini dapat dilakukan dan diberikan melaui pendidikan

persekolahan (pendidikan formal),

pendidikan luar sekolah (pendidikan

non-formal) dan pendidikan dalam

keluarga (pendidikan in-formal).

Pendidikan di Indonesia terbagi

menjadi tiga jenis pendidikan yaitu 
pendidikan formal, pendidikan informal dan pendidikan non formal. Menurut Coombs (1973) membedakan pengertian ketiga jenis pendidikan itu sebagai berikut: Pendidikan formal adalah kegiatan yang sistematis, berstruktur, bertingkat, berjenjang, dimulai dari sekolah dasar sampai dengan perguruan tinggi. Pendidikan informal adalah proses yang berlangsung sepanjang usia sehingga setiap orang memperoleh nilai, sikap, keterampilan, dan pengetahuan yang bersumber dari pengalaman hidup sehari-hari dan pengaruh lingkungan termasuk di dalamnya adalah pengaruh kehidupan keluarga. Peraturan pemerintah No. 73 tahun 1991 tentang Pendidikan Luar Sekolah mengatakan bahwasanya fungsi penyelenggaraan pendidikan Pendidikan Luar Sekolah adalah sebagai pengganti, pelengkap, dan penambah, terhadap penyelenggaraan pendidikan pada jalur pendidikan di sekolah.

Penyelenggaraan pendidikan non formal atau Pendidikan Luar Sekolah dimaksudkan untuk memberikan pelayanan pendidikan kepada masyarakat yang tidak mungkin terlayani pendidikan di jalur pendidikan formal. Salah satunya adalah Sentra baca atau perpustakaan. Sentra baca atau perpustakaan merupakan salah satu alternatif yang dapat dipilih dan dijadikan ajang pemberdayaan masyarakat.

Perpustakaan rumah pintar, merupakan salah satu satuan pendidikan yang berfungsi memberikan layanan pendidikan pada masyarakat. Secara tidak langsung perpustakaan rumah pintar dapat menjadikan penggunanya menjadi manusia yang sehat jasmani dan rohaninya, berkepribadian, cerdas, mandiri, maju, terampil, kreatif, professional dan produktif. Realitasnya penduduk miskin di Indonesia mencapai 26,58 juta $(10,12 \%)$ dari seluruh penduduk Indonesia. Kondisi ini berarti turun $0,52 \%$ jika dibandingkan dengan Maret 2017 yaitu 27.77 juta orang. Nilai ini juga membaik jika dibandingkan dengan September 2015 sebesar 11,13\% dan September $2017 \quad$ sebesar 10.70\%.Pemerintah terus berupaya mengatasi kondisi ini, baik di kota maupun dipedesaan.

Salah satu organisasi masyarakat yang berupaya untuk membangun organisasi Wanita Islam dalam melaksanakan berbagai kegiatan juga mempunyai Lembaga Otonom yang mengurus rumah tangganya sendiri 
sesuai dengan AD/ART dan Undang undang/ peraturan yang berlaku. Lembaga otonom ini dibentuk agar pengelolaan kegiatan lebih terfokus, lebih berkembang dan lebih mandiri untuk lebih meningkatkan efisiensi dan efktifitas. Organisasi Wanita Islam ini berdiri sejak tahun 2005, dan tepatnya berada di daerah Kp. Sawah, Klender Duren Sawit, Jakarta Timur. Di bawah naungan organisasi ini terdapat Rumah Pintar yang dapat mendukung masyarakat khusunya warga belajar yang aktif mengikuti kegiatan di Organisasi Wanita Islam ini dan di Rumah Pintar wanita Islam. Terdapat 5 sentra untuk mendukung pengembangan warga belajar disekitarnya, yaitu salah satunya sentra baca.

Pengelolaan perpustakaan di Rumah Pintar Organisasi Wanita Islam ini bertujuan untuk sarana pembelajaran seumur hidup dan terkait erat dengan peningkatan minat baca masyarakat secara umum, agar perpustakaan dapat berfungsi sebagaimana mestinya, pengelolaannya harus dikembangkan dan menjadi daya tarik pengunjung. Usaha yang dilakukan yaitu dengan menumbuhkan kompetensi warga belajar dengan diberikan pelatihan dan binaan tentang manajemen perpustakaan yang terlihat sangat berbeda dari perpustakaan umum biasanya, agar perpustakaan ini berfungsi dari warga belajar, oleh warga belajar dan untuk warga belajar.

\section{LANDASAN TEORI}

\section{Pengertian Manajemen}

Manajemen (Malayu S. P Hasibuan, 2005: 1) adalah ilmu dan seni mengatur proses pemanfaatan sumber manusia dan sumber-sumber lainnya secara efektif dan efisien untuk mencapai suatu tujuan tertentu. Manajemen adalah ilmu pengetahuan yang sistematis,agar dapat memahami, mengapa dan bagaimana manusia saling bekerjasama agar dapat menghasilkan sesuatu yang bermanfaat bai orang lain maupun golongan tertentu dan masyarakat luas (https//www.jurnal.id.blog.1 Nopember 2017)

Adapun dasar-dasar manajemen (Malayu S. P Hasibuan, 2005: 2) yang dapat meningkatkan kemampuan warga belajar agar dapat memanajemen (mengelola) perpustakaan Rumah Pintar Orgaisasi Wanita Islam itu dengan baik, sehingga dapat tercipta fungsi dari warga belajar, oleh warga belajar dan untuk warga belajar yaitu sebagai berikut : 
1. Adanya kerja sama diantara sekelompok orang dalam ikatan formal

2. Adanya tujuan bersama serta kepentingan yang sama yang akan dicapai

3. Adanya pembagian kerja, tugas, dan tanggung jawab yang teratur

4. Adanya hubungan formal dan ikatan tata tertib yang baik

5. Adanya sekelompok orang dan pekerjaan yang akan dikerjakan

6. Adanya human organization

Manajemen berorientasi pada hasil dalam pengimplementasiannya, yang kemungkinan terjadi kesulitan, terutama karena hasil (output) yang dicapai sesuai tujuannya, kadang tidak hanya bersifat material dan finansial atau tidak dapat dihitung dengan uang, sehingga sulit dibandingkan dengan masukan (input), dalam pergeseran tersebut manajemen cenderung diartikan sebagai "ilmu kemampuan menterpadukan. (mengintegrasikan) sumber daya yang dimiliki organisasi agar proses menghasilkan sesuatu produktivitas yang tinggi dalam rangka mencapai tujuannyayang berlangsung secara efektif dan efisien.

\section{Pengertian Perpustakaan}

Perpustakaan (Drs. Ibrahim Afdal, 2008: 3) adalah suatu unit kerja dari suatu badan atau lembaga tertentu yang mengelola bahan-bahan pustaka, baik berupa buku-buku maupun bukan berupa buku (non book material) yang diatur secara sistematis menurut aturan tertentu sehingga dapat digunakan sebagai sumber informasi oleh setiap pemakainya.

Salah satu ciri perpustakaan adalah adanya bahan pustaka atau sering juga disebut koleksi pustaka. Tetapi masih ada cirri-ci lain lebih mengarah kepada arti perpustakaan. Cir-ciri tersebut antara lain:

a. Perpustakaan itu merupakan suatu unit kerja (adanya perpustakaan tidak berdiri sendiri, tetapi merupakan unit kerja dari suatu badan atau lembaga tertentu. Sebagai contoh perpustakaan Rumah Pintar Organisasi Wanita Islam Duren sawit, Klender Jakarta Timur merupakan unit kerja rumah pintar Organisasi wanita Islam, perpustakaan universitas negeri Jakarta merupakan unit kerja UNJ, dan lain sebagainya)

b. Perpustakaan mengelola sejumlah bahan pustaka (di perpustakaan 
disediakan sejumlah bahan pustaka. Bahan pustaka bukan hanya berupa buku-buku, tetapi juga bukan berupa buku (non book material) seperti majalah, surat kabar, brosur, micro film, peta, globe, gambar-gambar, dan lain sebagainya. Jumalah bahan pustaka ini tergantung kepada kebutuhannya yang didasarkan pada jumlah pemakaiannya. Semakin besar jumlah pemakaiannya, maka bahan pustaka yang tersedia harus semakin banyak. Bahan-bahan pustaka tersebut tidak hanya disusun dan disimpan, tetapi dikelola dengan sebaik-baiknya menurut aturan tertentu, seperti diinventarisasi, diklasifikasi menurut sistem klasifikasi tertentu, dibuatkan kartu catalog, dilengkapi dengan lidah buku, label buku, kantong buku, kartu buku, sehimgga siap dipinjamkan kepada siapa saja yang ingin meminjamnya, khusus anggota perpustakaan.

c. Perpustakaan harus digunakan oleh pemakai (tujuan pengelolaan atau pengaturan bahan-bahan pustaka tidak lain adalah agar dapat digunakan dengan bsebaik-baiknya oleh pemakainya. Lebih jauh lagi adalah bagaimana agar dengan pengaturan tersebut dapat membangkitkan minat setiap pemakai untuk selalu mengunjungi perpustakaan. Dengan demikian, perpustakaan tersebut akan selalu digunakan oleh pemakai atau oleh anggotanya

d. Perpustakaan sebagai sumber informasi (perpustakaan tidak hanya sebagai tumpukkan buku tanpa ada gunanya, tetapi secara prinsip, perpustakaan harus dapat dijadikan atau berfungsi sebagai sumber informasi bagi setiap yang membutuhkannya. Dengan kaya lain, tumpukkan buku yang dikelola dengan baik itu baru daoat dikatakan sebagai perpustakaan, apabila dapat memberikan informasi bagi setiap yang memerlukannya.

\section{Pengertian Manajemen Perpustakaan}

Manajemen perpustakaan pada dasarnya adalah proses mengoptimalkan kontribusi manusia, material, anggaran perpustakaan yang didasarkan pada prinsip-prinsip dan teori-teori manajemen, untuk mencapai tujuan perpustakaan. Tugas mengelola (manajemen) perpustakaan dilaksanakan setelah organisasi yang menaungi telah mengangkat pemimpin/kepala perpustakaan. Keberhasilan pelaksanaan 
tugas dan fungsi perpustakaan tergantung kepada pemimpin perpustakaan tersebut.

Tugas manajemen terlihat pada fungsi-fungsinya dengan serangkaian kegiatan-kegiatan tertentu, meliputi perencanaan atas seluruh kegiatan, termasuk peralatan, waktu, sumber daya manusia, biaya dan lain sebagainya, kemudian pelaksanaan kegiatan yang harus dikendalikan diarahkan, dan diorganisasikan serta diberdayakan oleh pemimpin organisasi dengan mengerahkan seluruh kekuatan dan potensi yang tersedia.Secara rinci kegiatan-kegiatan itu adalah sbb :

\section{Perencanaan dan persiapan}

Perencanaan merupakan fungsi awal pengelolaan (Sudjana, 1992: 41). Menurut Sudjana (1992: 41) lebih lanjut perencanaan merupakan proses yang sistematis dan mengambil keputusan tentang tindakan yang akan dilakukan pada waktu yang akan datang. Kesistematisan itu juga menjadi dasar batasan perencanaan yang dikemukakan oleh Suherman, dkk (Sudjana, 1992: 41). Perencanaan adalah suatu penentuan urutan tindakan, perkiraan biaya, serta penggunaan waktu kegiatan yang didasarkan atas data dengan memperhatikan prioritas yang wajar dan efisien untuk tercapainya tujuan.

\section{Pengorganisasian}

Pengorganisasian merupakan sistem kerjasama sekelompok orang, yang dilakukan dengan pembidangan, dan pembagian seluruh pekerjaan/tugas dengan membentuk sejumlah satuan atau unit kerja, yang menghimpun pekerjaan sejenis dalam satu satuan atau unit kerja. Kemudian dilanjutkan dengan menetapkan wewenang dan tanggung jawab masing-masing, diikuti dengan mengatur hubungan kerjanya., dalam hal ini pelatihan manajemen perpustakaan dengan pengorganisasiannya yaitu mengatur bagaimana pengelolaan atau manajemen perpustakaan agar tujuan yang diharapkan tercapai.

Dalam pengorganisasian ini pula dibentuk langkah-langkah sebagai berikut:

- Menciptakan iklim atau suasana yang kondusif

- Mengatur tempat duduk bagi peserta pelatiahan agar dapat saling berkomunikasi dan bekerjasama dengan baik

- Mempergunakan metode bervariasi

- Mempergunakan alat atau media pelatihan yang dapat menunjang pelaksanaan pelatihan dan 
membantu peserta dalam menyerap informasi yang diberikan

- Mengelola kegiatan belajar mengajar dengan baik

\section{Penggerakkan}

Hal ini dilakukan setelah sebuah organisasi memiliki perencanaan dan melakukan pengorganisasian dengan memiliki struktur organisasi termasuk tersedianya personil sebagai pelaksana sebagai kebutuhan unit/satuan kerja yang dimaksud. Fungsi penggerakkan secara sederhana adalah untuk membuat atau mendapatkan para karyawan melibatkan apa yang diinginkan, dan harus mereka lakukan.

Fungsi ini melibatkan kualitas, gaya, kekuasaan pemimpin, serta kegiatankegiatan kepemimpinan seperti komunikasi yang terjadi, motivasi dan disiplin.

Penggerakkan sebagai fungsi dasar ketiga pengelolaan menurut para ahli memiliki posisi yang amat sangat penting dan strategis sehingga mutlak diperlukan dalam usaha kegiatan. Misalnya, seperti yang diungkapkan Siagian (1981: 128) bahwa fungsi organic penggerakkan dilihat dari segi filsafat administrasi dan manajemen merupakan fungsi yang sangat penting.

\section{Pembinaan atau pengarahan}

Pembinaan menurut Sudjana (1992: 157) merupakan rangkaian upaya pengendalian terhadap unsure-unsur itu berfungsi sebagaimana mestinya sehingga rencana untuk mencapai tujuan terlaksana secara efisien dan efektif. Hal ini pelatihan yang disampaikan dalam lingkup pemberian bimbingan, waktu bimbingan serta penentuan masalah yang dihadapi.

Hal yang dapat dilaksanakan yaitu:

- Mengarahkan peserta untuk mengetahui tujuan pokok pembahasan materi yang disampaikan

- Kominikasi dengan peserta (cara berbicara antara pelatih dengan peserta pelatihan selama kegiatan pelatihan berlangsung)

- Keaktifan mendengarkan peserta

- Melibatkan peserta dalam proses belajar mengajar

- Membimbing, membantu, dan memotivasi peserta

\section{Penilaian}

Hal ini berupa evaluasi yang dilakukan untuk menghimpun, mengolah, dan menyajikan data atau informasi yang dapat digunakan sebagai bahan masukan dan pemngambilan keputusan. Evaluasi dapat digunakan untuk penilaian pelaksanaan pelatihan, 
“penilaian pelaksanaan pelatihan mencakup penilaian terhadap proses, hasil, dan dampak pelatihan".

Penilaian dalam pelatihan manajemen perpustakaan ini pada dasarnya merupakan kegiatan yang dilakukan untuk mengukur sejauh mana hasil yang dicapai berdasarkan kegiatan yang dilakukan.

\section{Pengembangan}

Pengembangan menurut Morris (1992: 264) adalah upaya memperluas untuk mewujudkan potensi-potensi, membawa suatu keadaan secara bertingkat kepada, yang lebih akhir atau dari yang sederhana kepada tahapan yang lebih kompleks. Pengembangan yang dilakukan yaitu dalam hal perluasan program sertan bantuan untuk perpustakaan yang ada di Rumah Pintar Organisasi wanita Islam ini.

\section{Hakikat Rumah Pintar}

Rumah Pintar, menurut penjelasan yang dipublikasikan oleh SIKIB (Solidaritas Istri Kabinet Indonesia Bersatu) pada tahun 2008 merupakan nama bangunan yang berisi program pendidikan bagi ibu dan anak melalui berbagai sumber belajar.

Rumah Pintar menjadi salah satu solusi dalam persoalan ketertinggalan dan keterbelakangan masyarakat dalam bidang pendidikan untuk mengembangkan kualitas manusia dan masyarakat Indonesia. Rumah Pintar memiliki lima sentra, yaitu sentra baca, sentra permainan edukatif, sentra audio visual, sentra computer, dan sentra kriya. Pada penelitian ini, penulis memfokuskan pada masalah si sentra baca, yaitu lebih tepatnya pada perpustakaan Rumah Pintar Organisasi Wanita islam ini dengan pengelolaannya yang diharapkan memiliki manajemen yang sangat baik.

Rumah Pintar yang didirikan, yang berada dittengah-tengah komunitas masyarakat merupakan lembaga yang dapat menekankan kegiatan-kegiatannya dibidang pendidikan, baik ditingkat anak-anak usia sekolah, remaja, ataupun ibu-ibu yang lanjut usia. Pendidikan ini diberikan untuk segala usia, tidak mngenal usia, sehingga pendidikan yang diberikan berkesan pendidikan sepanjang hayat. Selain itu, membantu program pemerintah dalam meningkatkan kualitas hidup masyarakat melalui berbagai usaha layanan pendidikan, kesehatan sosial dan usaha mikro.

\section{Warga Belajar}

Peserta didik merupakan suatu komponen masukan dalam sistem 
pendidikan, yang selanjutnya diproses dalam proses pendidikan, sehingga menjadi manusia yang berkualitas sesuai dengan tujuan pendidikan nasional.

Sasaran ajar dalam pendidikan formal dan pendidikan nonformal terdapat perbedaan penyebutan. Perbedaan penyebutan tersebut anatara lain, sasaran ajar pada pendidikan formal disebut siswa atau siswi, sedangkan sasaran ajar pada pendidikan nonformal disebut peserta didik atau warga belajar.

Pengertian peserta didik atau warga belajar menurut UU RI tahun 2003 tentang Sistem Pendidikan Nasional pasal 1 ayat 4, "peserta didik atau warga belajar adalah anggota masyarakat yang berusaha mengembangkan potensi diri melalui proses pembelajaran yang tersedia pada jalur, jenjang, dan jenis pendidikan tertentu", sedangkan menurut Dra. Enung Fatimah, "Peserta didik/warga belajar adalah anak, individuyang tergolong dan tercatatsebagai siswadi dalam satuan pendidikan".

\section{METODE PENELITIAN}

Metode penelitian yang digunakan dalam kajianini yaitu metode deskriptif dengan teknik survey, penelitian langsung dengan populasi dan sample (responden) dengan 25 orang warga belajar dan 6 orang pengurus Organisasi Wanita Islam, Duren sawit, Klender, Jakarta Timur. Teknik pengumpulan data ini berupa observasi, draft pertanyaan untuk responden (wawancara), studi litelatur, dan angket.

\section{HASIL PENELITIAN}

Berikut hasil yang dilakukan dalam menumbuhkan kompetensi managerial perpustakaan warga belajar Rumah Pintar Organisasi Wanita Islam, yaitu sebagai berikut:

\section{Perencanaan}

Identifikasi awal yang dilakukan dalam perencanaan pengadaan perpustakaan (sentra baca) yaitu dengan melakukan wawancara kepada masyarakatmengenai buku-buku yang diminati oleh masyarakat.

\section{Penggorganisasian}

Pengkoordinasian perpustakaan rumah Pintar iniselain dengan para pengurus Organisasi wanita Islam juga dilakukan dengan masyarakat, atau khususnya dengan warga belajar itu sendiri. Agar perpustakaan ini mendapat dukungan dari masyarakat atau warga belajar ada berbagai fasilitas dan layanan lain untuk menambah semangat dari masyarakat atau warga belajar tersebut agar mau mengunjungi sentra baca atau perpustakaan ini. 


\section{Pelaksanaan}

Keberadaan perpustakaan Rumah Pintar Organisasi wanita Islam ini menjadikan masyarakat senang dan ikut memiliki. Merasa mendapatkan berbagai manfaat dari koleksi buku yang ada dan tersedia di perpustakaan Rumah Pintar Organisasi Wanita Islam ini ataupun dengan kegiatan-kegiatan yang diadakan oleh pengurus Organisasi wanita Islam ini. Pengelola perpustakaan ini mampu mengikuti kegiatan pelatihan untuk meningkatkan kemampuan dan pengetahuan, yaitu diantaranya: peningkatan minat baca, pengembangan model pengelolaan atau manajemen perpustakaan, dan manajemen pengelolaan perpustakaan.

\section{Pembinaan}

Perpustakaan Rumah Pintar Organisasi Wanita mendapatkan tambahan buku dari sumbangan khusunya dari pemerintah yang berkenaan dengan pendidikan.

\section{Penilaian}

Penilaian kegiatan perpustakaan atau sentra baca Rumah Pintar Organisasi wanita islam inidilakukan secara periodic meliputi perhari dilakukan dengan cek buku, penilaian perminggu dilakukan terhadap pengunjung, serta sarana dan prasarana yang ada.

\section{Pengembangan}

Pengembangan yang dilakukan Rumah Pintar Organisasi Wanita Islam ini, khususnya untuk sentra baca atau perpustakaan ini yaitu dengan mengembangkan bahan bacaan, mengembangkan program atau kegiatan yang menunjang kemampuan manajemen atau pengelolaan perpustakaan itusendiri, yang nantinya akan berdampak pada kebudayaan membaca masyarakat yang meningkat.

Hasil pemaran di atas dapat pula dijelaskan dalam langkah-langkah yang dilakukan, yaitu :

1. Dari hasil identifikasi, bahwa perpustakaan sangat diperlukan warga belajar Rumah Pintar Organisasi Wanita Islam, terlebih dengan pengelolaannya yang sangat diharapkan baik.

2. Sumber daya manusia pengelola mampu menjalankan berbagai tugas/peran, sehingga secara operasional perpustakaan Rumah Pintar ini dapat terus berfungsi walaupun salah seorangnya tidak masuk untuk bekerja sebagai pengelola tersebut, dengan memiliki berbagai pengetahuan dari berbagai 
pelatihan serta pembelajaran yang diberikan (terlampir dalam persentase dalam hasil analisis data)

3. Terdapat sarana dan prasarana yang baik (terlampir dalam hasil analisis data)

4. Perencanaan anggaran biaya untuk pengadaan bahan bacaan, peralatan serta sarana (terlampir dalam persentase dalam hasil analisis data)

5. Terbentuknya struktur organisasi perpustakaan (hal ini diberikan kepada warga belajar secara keseluruhan, agar disetiap bidangnya, mereka mampu untuk mengelola perpustakaan, sehingga seluruh warga belajar dapat merasakan serta berkemampuan untuk memegang disegala bidang yang terdapat dalam kepengurusan perpustakaan)

6. Pengembangan yang dilakukan dengan melalui kerjasama dengan pihak yang berkaitan dengan peningkatan perpustakaan (terlampir pada hasil presentasi analisis data)

Pembahasan

Petugas pengadaan dan pemeliharaan buku, khususnya untuk warga belajar yang telah dilatih terus dilakukan dan dikendalikan dengan intensif,sehingga mereka memiliki pengetahuan tentang penerbit, toko buku, penjualan buku, serta pemahaman kebijakan, prosedur pengadaan, praktek, dan kebijakan mengenai hadiah, serta pertukan buku. Mereka pula memiliki intuisi bibliografis agar mampu mendeteksi apakah sebuah buku dipesan dua kali , misalnya ada buku tengah dipesan atau sudah berada dalam daftar pemesanan. Pemeliharaan buku, warga belajar sebagai pustakawan ini telah mampu apabila tengara (tag) dibuku hilang, copot, atau kabur, segera diperbaiki. Buku yang perlu dijilid atau perbaikan segera diambil dari rak untuk perbaikan.

\section{PENUTUP}

Rumah Pintar Organisasi wanita Islam ini mengadakan pelatihan yang sekaligus dapat menumbuhkan kompetensi warga belajarnya sendiri dalam manajerial perpustakaan tersebut, agar perpustakaan dapat dikunjungi secara rutin, sehingga perpustakaan tersebut dapat berfungsi dari warga belajar, oleh warga belajar, dan untuk warga belajar, dengan artian perpustakaan dengan suasana yang lebih komunikatif itu ada dari warga belajar, diciptakan oleh warga belajar, serta 
manfaat perpustakaan yang dirasakan ada untuk warga belajar itu sendiri.

Di kelolanya perpustakaan atau sentra baca secara professional tentu dengan sendirinya akan menumbuhkan minat dikalangan masyakat untuk lebih memanfaatkan perpustakaan atau sentra baca Rumah Pintar ini secara optimal. model manajemen perpustakaan organisasi wanita Islam, dimulai dengan (1)perencanaan perpustakaan yang baik dan teratur, baik secara administratif,maupun dari sisi sumber daya manusia dan fasilitas pendukungnya sesui dengan hasil analisis kebutuhan warga belajar dan masyarakat.. meLatih warga belajar agar memiliki kompetensi untuk mengelola perpustakaan dengan baik.(2) pengorganisasian sumber daya yang tertib, termasuk pengadaan buku dan referensi yang sesuai dengan kebutuhan warga belajar dan masyarakat (3) pergerakan pada kegiatan pengadaan buku, penataan, perawatan dan penjagaan keamanan buku yang diminati warga belajar dan relevan dengan tujuan pendirian perpustakaan (4)Pembinaan, pembimbingan dan pendampingan pada warga belajar sesuai dengan kebutuhan belajarnya dan pembimbingan pada pengguna yang berasal dari masyarakat sekitarnya.

(5)monitoring dan pengawasan terhadap penggunaan sarana dan fasilitas perpustakaan agar terus strpembinaan pada ategis dan kondusif dalam membangun minat baca warga belajar (6) aspek pengembangannya, agar perpustakaan mampu memberikan layanan menyenangkan dan membangun motivasi belajar, baik dengan layanan teknis, nonteknis maupun yang sifatnya pengelolaan secara umum.

Luaran Penelitian adalah buku ajar, perpustakaan organisasi wanita Islam dikelola dengan fungsi-fungsi managemen yang efektif, dari warga belajar,oleh warga belajar untuk warga belajar dan masyarakat.Semua fungsi manajemen perpustakaan itu dikendalikan oleh pengelola, dengan mengerahkan seluruh pemikiran,energi dan kekuatan serta potensi yang mendukung kenyamanan belajar, serta menjamin interaksi yang transactional dialogic dengan pengguna perpustakaan. Akhirnya perpustakaan diharapkan terus berkembang, memiliki daya tarik dan memperkuat minat pengguna untuk terus membacanya,sehingga mampu meningkatkan pengetahuan, kekuatan mental,pola hidup dan keberdayaan penggunanya yang pada akhirnya secara 
bertahap mampu memberdayakan kehidupan warga belajar dan masyarakat.

Dampak yang dihasilkan atas pembelajaran yang dilaksanakan ini adalah semua akibat yang baik terhadap perpustakaan serta kemampuan warga belajar dalam mengelola perpustakaan tersebut, dengan kata lain perpustakaan tersebut makin berkembang, tumbuhnya kesadaran masyarakat atau warga belajar tentang pentingnya perpustakaan, tersebarnya informasi, ilmu pengetahuan, teknologi serta budaya, terjadinya perubahan pengetahuan, keterampilan, sikap atau perilaku masyarakat atau warga belajar pemakai perpustakaan.

\section{DAFTAR PUSTAKA}

Peraturan Pemerintah Republik Indonesia No. 73 tahun 1991 tentang Pendidikan Luar Sekolah. Jakarta : Gramedia

Bafadal, Ibrahim. 2008. Pengelolaan Perpustakaan Sekolah. Jakarta : Bumi Aksara

Direktorat Pendidikan Masyarakat, Ditjen PNFI, dan Universitas
Negeri Yogyakarta. Rumah Pintar, Taman Pintar, dan Komunitas Pintar. 2010. Kementerian pendidikan Nasional

Sudjana. 2000. Strategi Pembelajaran. Bandung : Falah Production

Hasibuan, Malayu . 2006. Manajemen Sumber Daya Manusia. Jakarta : Bumi Aksara

Sudjana, H. D. 2004. Pendidikan Non Formal. Bandung : Falah Production

Suryana, N. 1998. Perpustakaan dan Pembangunan. Perpustakaan Nasional RIMc Daniel, C.1998, Virginia View, 1979-1987 Journal of Career Development.Vo.14 (3).Spring 1988

Rice F.P. and Kim Gale Dolgin, (2008)The

Adolescent:development, relationships and culture,USA:Pearson Education

Paul Eggen and Don Kauchak (2004) Educational Psychology:Windows on Classroom (sixth edition:international edition) New Jersey:Perarson;Prentice Hall. 